\title{
A Processual Analysis of the Purchasing and Supply Organization in Transition The Impact of Offshoring
}

Mugurusi, Godfrey; Bals, Lydia

\author{
Document Version \\ Accepted author manuscript \\ Published in: \\ Operations Management Research
}

DOI:

10.1007/s12063-016-0119-7

Publication date:

2017

License

Unspecified

Citation for published version (APA):

Mugurusi, G., \& Bals, L. (2017). A Processual Analysis of the Purchasing and Supply Organization in Transition:

The Impact of Offshoring. Operations Management Research, 10(1-2), 64-83. https://doi.org/10.1007/s12063-

016-0119-7

Link to publication in CBS Research Portal

\section{General rights}

Copyright and moral rights for the publications made accessible in the public portal are retained by the authors and/or other copyright owners and it is a condition of accessing publications that users recognise and abide by the legal requirements associated with these rights.

\section{Take down policy}

If you believe that this document breaches copyright please contact us (research.lib@cbs.dk) providing details, and we will remove access to the work immediately and investigate your claim. 


\section{A Processual Analysis of the Purchasing and Supply Organization in Transition: The Impact of Offshoring Godfrey Mugurusi and Lydia Bals}

Journal article (Post print version)

CITE: A Processual Analysis of the Purchasing and Supply Organization in Transition:

The Impact of Offshoring. / Mugurusi, Godfrey; Bals, Lydia. In: Operations

Management Research, 27.07.2016.

The final publication is available at Springer via http://dx.doi.org/10.1007/s12063-016-0119-7

Uploaded to Research@CBS: September 2016 


\title{
A Processual Analysis of the Purchasing and Supply Organization in Transition: The Impact of Offshoring
}

\author{
Godfrey Mugurusi \\ Norwegian University of Science and Technology (NTNU) \\ Lydia Bals \\ University of Applied Sciences Mainz; \\ Copenhagen Business School
}

\section{Please cite as follows:}

Mugurusi, G., \& Bals, L. (Forthcoming): A Processual Analysis of the Purchasing and Supply Organization in Transition: The Impact of Offshoring, Operations Management Research.

\section{Introduction}

With more organizations today sourcing, manufacturing and distributing their products globally, the question of how best to organize raw material acquisition processes is increasingly drawing research and management attention. Many organizations have adopted the offshoring strategy in order to reduce costs, increase flexibility and enhance responsiveness in their operations (Tate et al. 2009, 2014; Sartor et al. 2014). Generally, the offshoring strategy involves "international relocation of disaggregated firm value chain activities in captive, collaborative or outsourced governance modes" (Bals et al. 2013:3). This paper particularly focuses on the captive offshoring governance mode, which keeps the activities in-house, but changes the geography where these activities are performed to an offshore location, in contrast to offshore outsourcing, which externalizes the activities to a third party or a hybrid mode such as a joint venture with a third party (Jahns et al. 2006; Contractor et al. 2010).

The objectives firms have pursued with offshoring do not always materialize. In fact, numerous studies have attributed the failure of the offshoring promise to high costs of knowledge transfer and administration (e.g. Stringfellow et al. 2008; Larsen et al. 2013; Srikanth and Puranam 2011). Empirical evidence has shown that firms struggle to re-organize entire operations when they engage in offshoring (Lampel and Bhalla 2011). This is further underlined by the recent surge of literature about the backshoring or reshoring phenomena (Kinkel and Maloca 2009; Kinkel, 2012; Gray et al. 2013; Ellram et al. 2013; Kinkel 2014; Fratocchi et al. 2014; Bals et al. 2015; Foerstl et al. 2016; Bals et al. 2016).

Therefore, finding the "right configuration" bearing in mind different cultural and economic contexts, operational capabilities, practices and routines is one of the most daunting challenges for companies (Mugurusi and de Boer 2013). Unlike hybrid and outsourced modes, captive offshoring has attracted modest research interest, yet it presents significant challenges in terms of setup costs amidst high uncertainty (Manning et al. 2008; Oshri 2011). Potentially facing increased coordination costs within the production network has been spelled out as a challenge in captive offshoring (Stringfellow et al. 2008).

In purchasing and supply management (PSM) literature, the challenge has manifested itself as one of reconfiguration and integration (Trautmann et al. 2009a) and in some other cases as one of organizational design (Rozemeijer 2000; Hartmann et al. 2008). For example, the establishment of new business units 
implies that previously unified PSM competencies are either lost or dispersed. Johnson and Leenders (2004) have described this as a process of dismantling of the PSM function. Amidst the complexity, the process of rebuilding of a new purchasing and supply organization (PSO) ensues (Tate and Ellram 2012). It entails finding the right mix of roles, people, procedures, purchase categories and control mechanisms across the world wide sourcing organization. The basis of which is fundamental to the success or failure of the offshoring strategy (Trent and Monczka 2003). That organizations operating geographically-dispersed facilities renew and reconfigure their PSO to cope with the uncertainties of the global market is of utmost importance to PSM effectiveness (Arnold 1999; Hartmann et al. 2008; Mol et al. 2005; Rozemeijer 2000).

Yet to date little is known about the implications of captive offshoring, especially the transition, on the PSM functions of firms. For example, Sartor et al. (2014:11) observe that "no research has been conducted so far to analyze how the migration of some industries to other sourcing or manufacturing basins (e.g. in the hunt for savings) affects the network of International Purchasing Offices (IPOs)". Therefore, our research objective is to develop knowledge and understanding of how the PSO and therefore PSM effectiveness is affected by the process of captive offshoring of production. We shall therefore be guided by the research question: How does the purchasing and supply organization (PSO) evolve as a result of captive offshoring of production?

By using a single in-depth case study of a company offshoring production as our context, we describe the change in each of five structural dimensions of the PSO. These five structural dimensions firmly established in the PSO literature include: Centralization, participation, formalization, standardization and specialization (e.g. Glock and Hochrein 2011). We explore what structural changes they make, when they make them and why they make these changes.

Theoretically speaking, taking a contingency perspective (e.g. Lawrence and Lorsch 1967), we extend the current knowledge on structural dimensions of the PSO with a dynamic, processual perspective, showing how the dimensions are changing over time. Reverting back to Galbraith (2012) and Ashby's law of requisite variety (1956), specifically the influence of increasing variety is emphasized. The disjointed and non-linear nature of PSO change processes is highlighted, which is a new finding in addition to the incremental and linked stage models available in literature. Methodologically speaking, we respond to the call for more "qualitative processual" research made by Tchokogué et al. (2011). They suggest that the processual perspective provides an ephemeral look into organizational change processes, which helps to explain how major and minor changes to supply structures occur and what enables these changes. Practically speaking, the way the PSO responds to organizational change presents opportunities to improve decision-making and resource planning across the entire organization (Kotteaku et al. 1995) and emphasizes mechanisms PSM can adopt in order to enhance organizational competitiveness (Mol 2003).

We begin by reviewing the current literature and the theoretical underpinnings to guide our research (section 2). Thereafter the methodology is presented (section 3). The results section includes the case description and the specific mapping of the PSO structure (section 4), which together inform the discussion of results (section 5). The paper closes with conclusions, managerial implications, limitations and suggestions for specific research directions (section 6). 


\section{Review of relevant literature: Characterizing the PSO over time}

The main literature that is relevant to this study will be discussed in the next sections, providing the foundations on: 1) How the PSO can be characterized (as the conceptual basis to describe these organizational changes over time), 2) the contingency view and the PSO (as the basis to conceptualize captive offshoring as the factor initiating the organizational adjustment process at some point in time put as $\mathrm{T}$ ), and 3) stage models of such change processes (as the conceptual basis to describe the processual analysis results).

\subsection{The key structural dimensions of the PSO}

To help us understand PSM's changes as a result of offshoring, we draw on the PSO structure literature because structure provides PSM the basis of organizing its activities for the attainment of organizational goals (Van Weele 2005; Quintens et al. 2006). Offshoring modes can be differentiated along the make or buy continuum into captive offshoring ("make"), a hybrid mode such as a joint venture with a third party or transfer of the activities to a third party as offshore outsourcing ("buy") (Jahns et al. 2006). As mentioned above, this paper particularly focuses on the captive offshoring governance mode. We contend that offshoring prompts the firm to change the structure of the PSM function in order to achieve functional and performance goals. The five most commonly adopted PSO dimensions in the literature are centralization, participation, formalization, standardization and specialization (Schneider and Wallenburg 2013; Glock and Hochrein 2011) and their respective definitions are shown in Table 1. Of these dimensions the centralization versus decentralization dichotomy is the most prevalent (Glock and Hochrein, 2011). One fundamental trade-off is between efficiency/control derived from centralization and flexibility/service level provided by decentralization (Kim 1990; Meyer and Curley 1991; David et al. 2002). This is also why over the last years hybrid models, combining both elements of centralization and decentralization have emerged in the PSM literature (e.g. Trautmann et al. 2009a; Trautmann et al. 2009b).

\section{Please insert Table 1 about here.}

Our definition of what constitutes the PSO is more in functional rather than in departmental terms (Dubois and Wynstra 2005), because the PSO scope has extended beyond a department responsible for the acquisition of a firm's raw materials, components, goods and services (Van Weele 2005) and can now be considered a facilitator of cross-functional value creation, a source of strategic advantages and more recently, a source of innovation and sustainability (Schiele 2012; Caniato et al. 2012). As such the deliberate use of the term "organization" in the paper is meant to emphasize the holism of this scope, also similarly found in previous literature (Johnson and Leenders 2004, 2006; Trent 2004).

\subsection{Contingency views on the PSO}

Building on the contingency theory which suggests that problems arise when structures are not well attuned to organizational contexts (Lawrence and Lorsch 1967; Pennings 1992), also the PSO structure is only temporal (Lampel and Bhalla 2011), since the firm faces varying levels of complexity at any particular period of time (Johnson and Leenders 2006; Espejo 2000). A mechanistic PSO with varying levels of 
centralization, participation, formalization, standardization and specialization may suit a certain level of variety experienced by the firm, compared to another period when an organic PSO with a different structure is best suited. The PSO structure has also been described as a "swinging pendulum", depending on how the variations manifest themselves (Tchokogué et al. 2011) and has been analyzed in terms of how these determine the ability to foster and manage innovation (Luzzini and Ronchi 2011). Also, whenever the firm undertakes corporate strategic initiatives (such as a major restructuring project), the PSO potentially has to change, too (Johnson and Leenders, 2001). In our study, the initiator of the change process is the decision to captively offshore production, to which the PSO needs to adapt in response.

The most common theory used in research on the PSO by 2011 was contingency theory (as shown by the five articles identified in 2011 by Glock and Hochrein in their systematic literature review), followed by transaction cost theory, open system theory, resource-based view, information processing theory, agency theory, experience curve and game theory (Glock and Hochrein 2011). But interestingly, most work that has been studying the linkage between offshoring or more general international sourcing, has not been utilizing contingency theory necessarily in a very explicit way. For example, Quintens et al. (2006) built their study, which highlights the link of global purchasing strategy on the PSO (standardization), on the resource-based view and add the suggestion to further study contingency factors to their future research implications. More lately, Tate and Ellram (2012) studied the impact of outsourcing services on the PSO (centralization, formalization, complexity) suggesting more research on the product setting, but do not mention contingency theory as such.

Looking at the literature that explicitly makes reference to contingency theory, but does not study a context closer to offshoring, we have, for example, the work of Stanley (1993), who developed a contingency model studying the effect of three contingency factors on the PSO (centralization, formalization, complexity/specialization), Lewin and Johnston (1996) who studied environmental uncertainty's impact on the PSO (participation, formalization, centralization) and the work by Rozemeijer et al. (2003) who highlight in their conceptual model that the business context (market, technology and business environment), corporate organization, corporate strategy and purchasing maturity (the level of professionalism in PSM) impact corporate purchasing synergy, structure and ultimately performance. Coming closer to the context of offshoring, following a contingency theory approach in the context of global sourcing, Hartmann et al. (2008) have studied contingency factors for PSO centralization. Therefore, in order to extend and bridge the gap between contingency theory-based PSO research and studying the context of captive offshoring, our research deliberately takes a contingency view.

Rooted in Chandler's (1962) work suggesting that structure follows strategy, proponents of the contingency view suggest that organizational effectiveness is in essence a result of fitting characteristics of the organization, i.e. its structure, to contingencies reflecting the situation of the organization (Lawrence and Lorsch 1967; Kast and Rosenzweig 1973; Pennings 1992). The organizational design characteristics of a firm should match the organizational context and firm's strategy in order to achieve performance improvements (Chandler 1962; Burns and Stalker 1961; Govindarajan 1986; Wasserman 2008). Context 
being the organization's operating environment, while structure being the mechanism in which organizational activities are organized.

Rozemeijer et al.'s (2003) suggestion that purchasing maturity (defined there as the professionalism of PSM) develops over time, adds an interesting temporal aspect to this processual study. According to Rajagopal and Bernard (1994) a less empowered PSM function lacks influence and therefore ability to make functional changes, which would have otherwise increased cross-functional integration or improve relationships with suppliers. Also in other studies such as that by Schiele (2007) purchasing maturity (defined there as the development level a PSO has reached) has been connected to some of the PSO dimensions (mainly standardization and formalization), again following the contingency notion that structure follows strategy. The latter connects this to the concept of absorptive capacity, which suggests that organizations learn more from their environment if their internal competence is high (Cohen and Levinthal 1990). Specifically, Schiele (2007) adds that the PSO influences PSM's absorptive capacity and also concludes that there is a minimum maturity point below which the introduction of best practices does not reap results, because the absorptive capacity of the organization is too low. In our study, purchasing maturity is therefore considered a potential influencing, temporal factor on the change process observed and will be discussed as such later on.

\subsection{Offshoring stage models and the PSO}

From a more dynamic view, Lewin and Johnston (1996) show that organizations varied their PSO structure when restructuring or implementing outsourcing. They add that initially PSM involvement in organizational decision-making is restricted yet centralization and formalization are high, but once stability ensues (i.e. less anxiety as a result of change) tight control and formalization reduce as participation increases. Also looking at changes over time, in an offshore outsourcing of services setting Tate and Ellram (2012) concluded that as organizations gained more experience in foreign markets, they became more risk averse and therefore tended to maintain control centrally, increased both formalization and specialization in PSM in order to insure themselves against opportunism within supply markets. This illustrates how these dimensions have been studied in the literature before, but how they have not yet been part of a processual analysis of how captive offshoring affects the PSO over time, which is the focus of our study.

Conceptually, offshoring is a process of organizational change (Kotabe et al. 2008; Srikanth and Puranam 2011). Handling the impact of offshoring requires firms to decouple and recouple the activity to the organizational configuration, while simultaneously ensuring that the activity's value creation potential is maintained (Andersson and Pedersen 2010; Lampel and Bhalla 2011). As a result, a number of theories and models have emerged to describe the state of change for offshoring phenomena. Some include: The internationalization process model (Johanson and Vahlne 1977; Johanson and Wiedersheim-Paul 1975); the evolutionary stage model of Kotabe et al. (2008); the transition process model of Tiwari (2010); the disintegration, mobility and reintegration perspective of Mudambi and Venzin (2010); the offshoring process of Srikanth and Puranam (2011) and more recently, the disintegration, relocation and reintegration process model of Jensen et al. (2013). At a broader level, the models and perspectives, although from different disciplines, are strikingly similar. In Table 2, we illustrate the common features (similar to how 
this has been done for international sourcing process models by Jia et al. 2014a) using the four most recurring phases across these sources.

Please insert Table 2 about here.

Turning towards how change processes have been characterized in the offshoring literature most stage models visualize offshoring as an incremental change process. Also akin to all is the idea that organizations involved in offshoring make changes as they proceed, a process most describe as organizational learning. Particularly Tiwari (2010) and Mudambi and Venzin (2010) suggest that the changes or improvements organizations make are linked and adaptive. Adaptation, according to Chakravarthy (1982), involves finding a state of fit between the organization and the environment which gives the firm some level of stability. Therefore, in order to maintain control and performance on an ongoing basis, the models suggest that attaining long-term stability is in fact the desired goal of an offshoring organization. The phases are characterized as follows.

Phase I constitutes the 'start' of offshoring. The models generally assume unchanged state of affairs. Kotabe et al. (2008) and Srikanth and Puranam (2011) suggest varying levels of operational involvement in international production activity.

In phase II, the preparatory phase suggests agreement of mode of operation on an ongoing basis (Tiwari 2010). The slicing and dicing of value chain activities for dispatch ensues (Jensen et al. 2013). And since the organization is in state of 'disintegration', most roles and job functions are not well specified. The control over ongoing work processes is based on internal information and communication exchanges rather than clearly defined patterns and hierarchy (Schilling and Steensma 2001). The distinction between phase II and phase III is often blurred because of parallel operations between the foreign business and the domestic business unit (Srikanth and Puranam 2011).

In phase III, the actual migration ensues. The firm makes changes in respect to local demands and market characteristics. By creating new and/or modifying old roles, processes and structures, it is possible to find a temporary operating model (Tiwari 2010). The firm must, overall, be flexible and capable of handling multiple change routines without losing control of the market (Beer 1985; Espejo 2000).

In phase IV, some level of re-organization is sought by validating the changes made at earlier phases and building on the experience by making continuous improvements (Tiwari 2010). This stage may be the most critical (Kotabe et al. 2008). Establishing the right configuration and alignment of internal and external capabilities may lead to attainment of desired efficiency levels (Beer 1985, Espejo 2000).

In practice, stage models have numerous drawbacks and have, as such, attracted strong criticism in literature. There have been questions as to whether the change process described in stage models was continuous or infinite (Dawson 1994); whether some stages in the process overlap; or whether there is prolonged discontinuity across stages of the process (Van Weele 2005). It is partly for this reason that this study adopts the process perspective to remedy these concerns. The other reason is what sequences and events never tell: Changes and events in the PSM function often occur at different levels and different times, compared to other organizational events. Variations can be attributed to a number of factors 
including: The reporting level of the PSM function (Pearson et al. 1996; Day and Atkinson, 2004), alignment of organizational goals and PSM goals (Johnson and Leenders 2004) or in some cases, type of culture in which the PSM function is embedded (Rajagopal and Bernard 1994). This fundamental aspect of PSM change is unfortunately often overlooked in literature. However, we came across three studies which do attempt to show how PSM change occurs in reality: Matthyssens et al. (2003:322) propose a model of global purchasing change implementation. First, they show global purchasing as a gradual process involves learning. Second, they suggest that progression in international purchasing requires companies "to balance the drivers for internalizing their supply networks against the inhibitors they might encounter while doing so". Next, Day and Atkinson (2004) show that implementing change in PSM is a non-linear and unstable process; preconceived change models do not capture the social processes in which structural changes occur. Finally, Tchokogué et al. (2011) map ongoing change in supply structures over a period of time. They report that organizations from time to time adjust their supply structures to allow flexibility but mainly as an adaptation mechanism to ongoing changes in the business environment.

Also, though not focusing exclusively on the impact of the PSO, Lampel and Bhalla (2011) have suggested in their study on evolution of organizational configuration in response to offshore outsourcing that in case it is low-added value activities that are in scope, loose coupling is sufficient, but in case companies turn to offshore outsourcing of high value-creating activities that require tight coupling to the configuration problems can occur. To the best of our knowledge, such studies do not yet exist for the setting of captive offshoring.

These studies therefore put forward two aspects that are central to the understanding of the PSO change activity during the offshoring process: (1) Organizational change processes, such as offshoring, are influenced by both external and internal undercurrents, hence the variations. The choices managers make, the resource envelope of the organization and the relational rents of the firm determine how an organization builds momentum in a transition process (Chakravarthy 1982); (2) Although PSM's structural change processes are embedded in other organizational change processes, the PSO takes on different adaptive states at different phases of the respective change process.

\section{Methodology}

\subsection{Case study approach and processual analysis}

As mentioned in the introduction, our research objective is to develop knowledge and understanding of how the PSO and therefore PSM effectiveness is affected by the process of captive offshoring of production. This was captured in the research question "How does the purchasing and supply organization (PSO) evolve as a result of captive offshoring of production?". Given the strategic importance of offshoring decisions in most firms (Contractor et al. 2010), one would expect that how the PSO is reorganized and repositioned to respond to these decisions would be well-studied. Unfortunately, this phenomenon has had little coverage in the literature, hence the exploratory nature of this study. The analysis is based on a single in-depth case study within a large multinational engineering company. Case 
studies can generate new insights and are regarded useful for building new theory (Stake 1998; Gephart 2004; Yin 2009; Gioia et al. 2013; Stuart et al. 2002; Barratt et al. 2011; Ketokivi and Choi, 2014).

We position this paper in the evolutionary change perspective, a familiar angle of most offshoring process research, hence the processual analysis adopted in the study (Pettigrew 1997). Such processual approaches have been suggested to get a holistic and dynamic analysis of change (Greenwood and Hinings 1988; Van de Ven and Huber 1990; Pettigrew 1990; Hinings 1997; Dawson 1997; Pettigrew et al. 2001). A processual analysis seeks to analyze the sequential interconnectedness among phenomena over time. As put by Pettigrew (1990:269) it is contextualist in nature as "an approach that offers both multilevel or vertical analysis [structural transformation of the corporate level and PSO level in our case] and processual, or horizontal [interconnectedness among structural changes over time in our case] analysis". Following this, we empirically investigate how each of the five structural dimensions of the PSO changes during the offshoring process, and why the changes occur in the manner they do.

Although the processual approach was the dominant method used in this study, which is consistent with studies of Day and Atkinson (2004) and Tchokogué et al. (2011), we gathered both historical and retrospective data as well as current data. The actual act of offshoring occurred in the past (spring 2009) and the data collection began in the fall of 2011. We anticipated this would be challenging since, naturally, the human mind is incapable of recollecting all past events. As a solution, we used the critical incident technique (Flanagan 1954), which allowed the collection of key historical data from observations, site visits and past staff historical accounts. A number of milestones were identified from secondary data, along which informants during interviews were asked to reconstruct facts around a list of notable ("critical") incidents regarding events and actions of key people within the case (for more information on primary and secondary data collection please see Appendix A). The use of multiple research techniques strengthens rigor of case research and improves validity and reliability of research findings (Bryman and Bell 2011).

\subsection{Case selection, unit of analysis and data collection}

NorTex (a pseudonym) is our case company. For confidentiality purposes, the company's name has been anonymized. The firm is part of a large industrial conglomerate with research, manufacturing and sales facilities all over the globe. The firm had been involved in offshoring its production and procurement operations from Europe to a relatively new production facility in Asia. Since this paper investigates what happens in the purchasing and supply management (PSM) function over time in response to offshoring production, we elected to study the problem following a hint by one of Nortex's supply chain management executives in 2009. In a guest lecture session attended by one of the authors of this paper, the executive was concerned about the tensions between the PSM function and the production function that had affected the firm's cost and quality objectives. At the time, the company was in the process of offshoring its production operations to its facility in Asia.

The choice of this case fits the research context in two ways: Firstly, it was possible to adopt a process perspective using both historical or retrospective and current data. Process studies are rare in the PSM discipline (Tchokogué et al. 2011), yet if carried out well, they tend to provide irrefutable explanations of how organizational phenomena 'become' (Langley 1999). Secondly, although it is common 
knowledge that organizations often change their PSO structures in order to maintain control of both internal and external resources (Johnson and Leenders 2003, 2004, 2006), little is known about "how" the changes are enacted during actual offshoring of production. Although the single case study approach inherently limits generalizability of this research, the NorTex case provided an unusual, yet unique, opportunity to learn about how PSO structure is formed and elaborated 'in action' (Stake 1998).

The unit of analysis (UoA) is a function and its organizational set-up, i.e. the PSO. At commencement of the study in 2011, a "new" PSO was beginning to emerge following the full merger of procurement activities of the two business units i.e. the European business unit (hereafter; EUBS) and the Asian business unit (hereafter; ABS) in 2010. In 2012, the head of the Purchasing and Supply Unit (HPSU) provided access into the firm and into this "new" PSO.

By design, we collected two types of data, i.e. historical or retrospective data and real time data. These together included the following sources of evidence: Semi-structured interviews (face to face and non-face to face), websites and archival records (e.g. press releases, worksheets, written memos, company financial reports, supplier workshop presentations, project documentation and company training documents; for more details please see Appendix A). Also site visits were made at firm's production facilities in Asia and Europe. Four specific observations were made at the shop floor of both facilities and notes taken. At the ABS facility, the process of assembling standard products was observed, while at the Europe facility, the machining process of an Air Control Unit (ACU) and the process of fitting ACU connectors were observed. In addition, the process of mounting the product onto a dummy production line was observed over a period of time to understand how PSM supports the other functions, including manufacturing and engineering. In using multiple sources of data, the study aimed at enhancing descriptive validity of case study outcomes (Yin 2009). Interviews were the primary source of data (for more information on primary and secondary data collection please see Appendix A). These were completed, transcribed, and coded into NVivo 10 software, together with all other data. The 12 informant's details are shown in Table 3.

Please insert Table 3 about here.

The process of analyzing data began by a write up of the case description from field notes, observation summaries and interviewer logs. This was done in constant feedback and engagement with the informants. Lincoln and Guba (1985; cited after Westbrook 1994:251) suggested that this is “...the most crucial technique for establishing creditability". We proceeded with coding the transcribed interview sheets and running a series of queries in NVivo including grouping and word frequency. In particular, the word frequency query is meant to ascertain the consistency and accuracy of thoughts of study participants. The open coding method was used (Gioia et al. 2013) since the interest of the paper were experiences, thoughts and actions of informants that are and were responsible for the firm's PSM operations during offshoring transition, we initially coded for time periods and critical events that occurred during those periods in order to construct a timeline (for more information on data analysis please see Appendix B).

\subsection{Brief case description}


NorTex is a global original equipment manufacturer (OEM). The company manufactures automation equipment for the plastics and consumer electronics, automotive, metal fabrication, foundry, wood, machine tools, pharmaceutical and beverage industries. It is part of a large global engineering corporation with over 150,000 employees and revenues of about $\$ 35.5$ billion (as of 2015). NorTex is a 2,000 employee organization that specializes in two product groups ( $\mathrm{X}$ and $\mathrm{Y}$ ), although numerous customized and industry specific variants are manufactured as well. Besides these two broad product groups, the firm is also supplier of peripheral equipment (e.g. specialized motor and gear units) and other services (e.g. end of life services and remote data backups). Within NorTex, the focus of research was the purchasing and supply unit which was responsible for identifying suppliers, providing specialized input in product development processes, total procurement support and managing logistics of parts shipping, delivery, handling and quality control. Although the problems of production offshoring generally affected both product groups (X and $\mathrm{Y}$ ), we focused on the manufacture of product group $\mathrm{Y}$, because it was solely produced at EUBS before offshoring; AISR, a separate business unit, occasionally assembled modules of the two product groups for the Asian market (more detailed information on product $\mathrm{Y}$ can be found in Appendix C).

\section{Processual Case Analysis}

The analysis proceeds along the different phases within the project, summarized in Figure 1 and the key decision points of each phase are presented in Figure 2. Each sub section highlights the organizational changes on corporate and specific functional PSM level. Concerning the latter, the specific changes concerning the five PSO dimensions are also summarized in Table 4.

Please insert Figure 1 about here.

Please insert Figure 2 about here.

Please insert Table 4 about here.

\subsection{The status quo at EUBS - before 2005}

Before 1999 Nortex had established a subsidiary in Asia. At the time the subsidiary was set up as a facility to produce low-cost components to support the European and American business units. Three years later, NorTex also established a facility to assemble modules of product $Y$ for the EUBS. Initially, the internationalization decision was driven by the relatively low cost of labor and access to the Asian market. However, with the declining market for product $Y$ and the economic downturn in Europe before 2006, the company decided to relocate the production of product category Y from the European facility (EUBS) to the Asian facility (ABS) in 2009. It also seemed reasonable to follow some large customers and suppliers to Asia. Indeed, as close to $50 \%$ of the firm's sales were from Asia and suppliers of the most strategic components, especially for product group Y, were largely Asian companies.

Prior to the decision to offshore production, the firm had been sourcing components from the Asian market with the help from its satellite business, ABS. Although a somewhat independent business unit, 
ABS was physically close to Japanese suppliers of the strategic components. It had independent supply "engineers" (not purchasers) who would work with the EUBS purchasers and R\&D staff to communicate design requirements to suppliers in Asia. The sourcing model was considered flexible, agile commercially viable and to work well.

Therefore, the first steps of transition within the PSO were the establishment of linkages between the two BUs, mainly to deal with the ever increasing variety in the EUBS. However, the state of variety was relatively low because internal alliances were established and worked well. The PSO constituted two decentralized and independent PSM units within each business unit. The set-up provided a stronger customer orientation, responsiveness and more direct product responsibility. The interface between the two business units was transactional given that each BU had independent supplier databases, although some, especially for strategic components were shared as summed up by the HPSU that: “...purchasing was in between production and R\&D."

As such, there was little formalization since the role of the purchaser was relegated to generating bills of materials, negotiating price and terms of delivery with suppliers. And even then, PSM personnel were most times needed only on ad-hoc projects where it was perceived they contributed by reducing sourcing lead-times. R\&D engineers would engage suppliers without full buyer involvement. Standardization too was low as in both facilitates as suppliers were literally designed into the products.

\subsection{The preparation phase at EUBS \& ABS - between 2006 and 2008}

In the subsequent preparation phase the firm anticipated an improvement in the market slump starting 2006. However, statistics from the industry federation predicted higher growth on the Asian markets (22\% compared to Europe's $11 \%$ ). In response, Nortex relocated its global headquarters from USA to ABS in 2006 and began expanding local R\&D capabilities. The PSM department at ABS had expanded as well in order to support increasing assembly of EUBS modules. And since the interaction between the factories had improved, a production support team had emerged within the PSO to support PSM by providing a technical service of interpreting technical EUBS R\&D drawings, as well as all "production issues e.g. sales, production, testing and quality. At that time we were still based in [EUBS] R\&D and still [EUBS] R\&D personnel" (interview: TM).

The notion of extended supply unit was beginning to emerge with cross-functional and crossbusiness team operations. The position of the global commodity manager (GCM) was created to oversee cross-functional teams responsible for strategic categories and also drive global sourcing synergies in the two BUs and another independent factory in Europe especially for a key component with $35 \%$ of total spend. It was therefore imperative that global sourcing and category management strategies across BUs were implemented. Cross-business unit interactions increased, but the PSO remained decentralized. Some level of work instructions to, for example, perform how to implement engineering change orders (ECO) in SAP were necessary. Unlike EUBS, the ABS facility had started to make changes in procurement. For example, instructions on how to implement engineering change orders (ECO) in SAP were initiated. Participation increased as BUs discovered that they shared common components, even across several product groups. 


\subsection{The actual migration phase from EUBS to ABS, 2009}

In 2008, signs of Europe going into recession had started to emerge and the end of 2008 signaled an eminent move to relocate production along with the PSM function to Asia.

“...production volume dropped dramatically. So [EUBS] went from producing 400 to 500 units in 2008 down to less than 100 and in half a year, we had 2 units order intake. So [...] they were not taking a strategic decision [but it was the realization that] OK, now we move it to a lower cost base, [or] we would be bankrupt, we would have stopped, we would have stopped!" (interview: HPSU).

In spring 2009 the firm decided to move all production and procurement operations from EUBS to

ABS. The R\&D function alone was retained at the EUBS. Some personnel in production and procurement relocated to ABS to train and work with their counterparts in Asia. The physical machinery and some ongoing projects were moved as well; part of the old factory premises were rented out to another firm. The EUBS teams prepared standard operating procedures, tools, checklists and the like, which were filed and shipped to ABS in order to facilitate rapid knowledge transfer. In addition training workshops were done continuously. The physical movement of machinery and other technical apparatus almost brought the organization to a standstill with almost zero order intakes during the period. The firm struggled with tremendous variety, both internally and externally especially having done little in preparation which had a direct impact on the internal operations, suppliers and customers in the short run.

Within the PSO, the decision-making power swiftly moved to category management teams, especially for the high spend items. The PSO structure in this phase can be described 'fluid' with some few features of center-led procurement (reminiscent of a hybrid organization, but not yet fully developed). Management had placed significant amount of pressure on shared service teams and global teams to keep lead times shorter and on-time delivery (OTD) uninterrupted, but this was hindered by a lack of clearly defined PSM responsibilities. A senior purchasing executive reminisced:

"It was decided in the initial plan. That we should build the competence here but [...] that has not happened. We are still on a quite low level of local technical competence [and] that has remained in [EUBS]. Why it has not been transferred? There are a couple of reasons, there is no pull from this organization, there is [none whatsoever]. We do not suck in and want it, as long as we know that there are competences available in [EUBS], we don't pull this. Of course [EUBS] side they don't push. Of course why should they push? They are closing [down] their own work. So and then, I don't see it as a [ABS] problem or [EUBS] problem, it's a management problem".

Generally, responsibilities were not clearly defined. Another change champion described this disordered period as a period of "indecisiveness" (Report by: Project Manager\#5), while the Tactical Purchasing Manager (TPM) commented:

"I think everything cannot be defined clear. This is the line you cannot cross. It's a lot of grey area. We just cross a step".

To support further re-organization, it was decided to codify and standardize processes in order to improve technical knowledge transfer for more specialized roles. Unlike R\&D, downsizing at EUBS had affected PSM most; only one senior executive had been transferred to ABS to kick start the procurement operations there. Standardization was dictated upon by the firm's product development framework, which basically became a standardized knowledge repository for the knowledge of EUBS product development engineers. But over time, the involvement of PSM personnel in product development, especially at ABS, became inevitable; especially if a shared work item list was used and to be maintained for ongoing service levels. 


\subsection{The reorganizing phase - from 2010 onwards}

After 2009, many operational problems occurred which had major impacts on the overall firm performance. Management began the process most informants described as 'trying to make it work' using the new and broader supply chain view to recapture and gain control of the firm's value creation processes.

"What we are working on are: time to market, flexibility and lead-time and this area to get a flexibly supply organization. And by that, we are arranging all the supply flow from sub-suppliers to our factory. We are kind of rebuilding the structure for supply chain as we speak, and that's the consequence of relocation as well. We have focused so much on localization and try to get back track on the delivery and we have had backlogs since 2010, [yet], we [... are] operating in the increasing market" (interview: GCM).

To cope with the tremendous variety it was important to stabilize internal structures for the new market. One way they successfully did this was through internal process optimization and reconfiguration of the entire supply chain, which amidst uncertainty at least helped to some degree to restore the initial variety balance.

More specific changes had been made in the PSO. One of the most pronounced change aspects in this period was the decision to centralize the entire purchasing and supply operations at ABS, with entire sourcing activities performed by personnel at ABS. After that rather "fluid" phase III, in which the organization was not clearly guided by any particular rules, first came the progressive alignment and optimization of supply strategies by aligning supplier databases, then consolidating goods between factories, vendor managed inventory or call-off hits and other measures. More rules were made, particularly with regards to approval of parts, supplier selection and how PSM would interact with design engineers given the geographical distance between ABS and EUBS. Along that the level of specialization had increased as several departments within the PSU were now differentiated - sourcing, technical support to engineering, supply quality, tactical procurement and global commodity teams. In total, the entire PSU alone now consisted of over 50 employees.

Yet despite these ongoing changes, a senior manager was quick to admit that robustness of the new supply structure was still not reached (interview: HPSU), because:

“... [ABS] didn't have a good system initially for handling the parts which arrived from the suppliers and lot of parts [were] combine[d]. They didn't know where [parts were] because [they were] not coming to the source location. [They] didn't actually in the beginning have a good system, now we have managed to get better system. They have assigned other location where they receive all the parts and but even though this is not functioning 100\%." (interview: Project Manager\#2). New rules and procedures were now also in place on how purchasing would interface with $R \& D$ - through the production support. "...we have a default rule [that only] R\&D contacts R\&D” (interview: Project Manager\#1).

In general, PSO centralization had increased the level of specialization in the PSO, however participation had declined once relative stability had been attained due to the geographical distance factor and feeling of disenfranchisement among EUBS engineers. A former project manager who sounded quite unsatisfied thus observed that:

“... structure increasingly felt like it was limiting the opportunities of cross-discipline interaction...nobody had any feel for the product...".

The result was a deeply disjointed organization and a less integrated buying center. Furthermore, because the firm had rapidly formalized, the material acquisition process had become more complex and 
less nimble, while over-specialization had reduced communication across and functions. Hence, temporarily PSM had become rather mechanical and inflexible to make further changes and improvements.

\section{Discussion of case results}

The objective of this paper was to understand changes the firm makes in its PSO during captive production offshoring, by addressing the following research question: How does the purchasing and supply organization (PSO) evolve as a result of captive offshoring of production? This section discusses the main case study results, from which 10 propositions (5 main propositions with sub propositions) are developed. The resulting framework featuring the developed propositions is shown in Figure 3.

Please insert Figure 3 about here.

The case illustrated that as the firm is faced with varied complexities in every step of offshoring, it makes varied adaptations in procurement operations. This is partly a mechanism of maintaining functional operationability and organizational stability and partly a mechanism of organizational learning. In line with theory, the adaptations are driven by the law of requisite variety (Ashby 1956:207) which states that "variety within a system must be at least as great as the environmental variety against which it is attempting to regulate itself". In this case it entailed the firm matching its organizational capabilities to market demands (similar to these studies, but for other contexts: Siggelkow and Levinthal 2003; Valle et al. 2015). Thus, we propose:

Proposition 1a: In response to increasing external variety the firm increases its internal variety by matching its internal capabilities with the external market demands in the initial stages of the offshoring process.

The case depicts organizational adaptation as a stage process in the captive offshoring of production. As the firm becomes more involved in the captive offshoring process, management complexity (described as variety) increases, and later reduces because the firm builds its internal capabilities through leveraging its relationship with the local subsidiaries, their networks and their embedded market knowledge. Management complexity majorly results from the limited knowledge about the new environment, the market, suppliers and customers (Zaheer 2002). However, because the firm has pre-existing structures such as interdependences between subsidiaries, cross-business unit communication structures and flexible role designs, it paves way for scaling up these shared interfaces as an internal capability which later transitions into a shared identity across the firm (Vlaar et al. 2008; Jensen 2009). This reduces communication and coordination costs, increases standardization and hence reduces complexity. Thus, we propose:

Proposition 1b: Increasing internal capabilities facilitate processing of the external variety and the firm subsequently reduces its internal variety in the later stages of the offshoring process.

In the beginning, PSM's role in the firm's decision-making processes was obscure. As introduced in section 2, low purchasing maturity is characterized by transactional/price focus and limited influence in organizational processes (Rozemeijer 2000). In the case, what constituted PSM versus non-PSM activities was unclear. However, three features were distinct: (1) most products were design-to-order; (2) product development was highly embedded in PSM decision-making and (3) PSM activities were decentralized 
locally in business units. This set-up facilitated control of supply and demand simultaneously and reduced supply chain uncertainty. Unfortunately, the set-up had also crowded PSM out of decision-making. In line with previous research (Pearson et al. 1996), the PSM function's position in the back seat hindered its ability to suggest or make any improvements. The question arises if actually the aforementioned benefits of decentralization should not have been maintained more within a new structure, instead of radical centralization efforts without taking them into account. We regard the neglect of that option as a result of the low purchasing maturity in the case. Thus, we propose:

Proposition 2: Low purchasing maturity in a highly decentralized PSM function inhibits the PSO's ability to suggest improvements during phase I (status-quo) as input for stage II (preparation) of the offshoring process.

The case study evidence suggests that minimal changes were made in the PSO until the actual decision to offshore production was taken. These changes were mainly ad hoc. Before the offshoring decision, there were slight changes in formalization, specialization and participation, especially at the knowledge receiving business unit. Only at that point, new rules, roles and teams were initiated. Thus, we propose:

Proposition 3a: Ad-hoc momentum to make changes to the PSO increases during phase II (preparation) of the offshoring process.

According to Bourgault et al. (2008) more formalization and participation improve cross-functional communication and speed up decision-making cycles. It has also been suggested that formalization and participation enhance team formation and knowledge dispersion (Hult et al. 2003), while specialization promotes efficiency within job tasks (Stanley 1993) and facilitates knowledge and competences build up within the supply organization. Hence, we regard these preparatory changes as a way to prepare the PSO for learning. Learning is a fundamental enabler for transfer of knowledge and practices from one entity to another. Hult et al. (2003) concede that learning in supply management involves a set of orientations which include: Teams that are willing to share knowledge; a system view of supply interconnectedness; learning as an enabler of good performance; and willingness to maintain knowledge sharing within the supply organization. In that sense, organizations prepare themselves to learn by disbanding processes or activities that limit their acquisition and sharing of knowledge, while adopting those that enhance acquisition and sharing of knowledge (da Silva Gonçalves Zangiski et al. 2013). Thus, we propose:

Proposition 3b: Increasing formalization, specialization and participation in the PSO are the main antecedents to knowledge transfer and learning during phase II (preparation) of the offshoring process.

The case evidence suggests that corporate management took temporary control of the PSO activities to ensure that organizational goals were achieved during the actual offshoring process. Rigid executive intervention in the PSM function meant almost nothing was changed. The span of authority in PSM was vaguely defined. Formalization remained moderate, while standardization and specialization remained low. Only participation increased, as the use of cross-functional teams increased. The focus on specific strategic commodities and formation of teams around these meant PSM for the 'non-strategic' items was almost chaotic. As has been suggested by previous research, maintaining ongoing support to organizational supply needs may be perceived as a higher priority in disruptive environments, than focusing on the long term organizational aspects (Whitney et al. 2014). We described this form of organization as "fluid". The PSM 
function was overwhelmed and almost nothing was done about it. The events from the case show that offshoring of production is disruptive. There are various uncontrollable forces that affect organizational operations progress onwards (Stringfellow et al. 2008). These include the tensions between geography and culture on one hand and maintaining ongoing operations and increased dependences on the other hand (Bals et al. 2013). Many changes are ongoing such that maintaining PSM stability is almost impossible (Day and Atkinson 2004). In addition, structural inertia theorists have long suggested that organizational practices and routines are costly to change and if rapidly changed, organizational instability may occur. This explains why the firm is hesitant to change its structure, partly because of the politics and risks involved with radical changes (Colombo and Delmastro 2002). Thus, we propose:

Proposition 4a: A "fluid" mode prevails during phase III (actual migration) of the offshoring process.

Furthermore, our case evidence suggests the increased use of centrally coordinated teams, crossfunctional sourcing processes and more specialized PSM groups during this phase in offshoring. Also, PSM personnel were now occasionally involved in R\&D processes such as the ECO (Engineering Change Order) processes. These changes suggest increased PSO involvement.

The involvement construct is linked to perception and recognition (Pearson et al. 1996). When the PSM function is perceived as an important party in organizational processes, its influence and access to information increases, and so does its ability to contribute to organizational performance (Pearson et al. 1996). As a knowledge repository during unstable periods of the firm's transition process, PSM's role expands as a coordination platform for cross-functional teams across business units. Besides, dispersed teams need a lot of information to coordinate their respective internal processes in order to minimize conflict (Chung et al. 2004). Any business model or unit that emerges to align firm goals, increases collaboration and reduces conflict at team and organization levels, plays a strategic role. In this case, PSM played that important role. Thus, we propose:

Proposition 4b: The "fluid" PSO structure creates favorable conditions to improve PSM's participation in cross-functional teams and cross-business unit processes during phase III (actual migration) of the offshoring process.

Once production offshoring is complete, firms will reorganize entire operations for the purpose of leveraging collective opportunities at a global level (Mugurusi and de Boer 2013). Particularly, if the decision to relocate production operations was motivated by access to global markets and cost reduction, rapid changes are made in order to understand the new market and regain control of cost (Contractor et al. 2010). The centralization of PSM activities has been considered one of the most straightforward ways of securing both benefits, i.e. control of external spend and increases in economic benefits (Trautmann et al. 2009a). Centralization also increases distance and tensions across business units (Hartmann et al. 2008). Evidence from the case indicates that overall the firm had transitioned from a decentralized setup to a fully centralized PSO. Full centralization had prompted more formalization, more standardization and more specialization. Surprisingly the level of participation had declined at the EUBS and increased at the Asian business unit.

The case furnishes a more pertinent and perhaps a strategic reason why production offshoring firms centralize their PSOs, i.e. it improves visibility of external spend amidst uncertainty. Since the firm is 
recovering from a disruptive offshoring process, cost and risk prognoses are less reliable. The centralization provides a shorter and specialized cost reporting structure, which increases spend visibility, improving cost control (Van Weele 2005). Through central coordination and specialized control, demand and the associated costs are visible, reducing uncertainty. Thus, we propose:

Proposition 5a: Increasing centralization of the PSO improves spend visibility and offers a cost control mechanism during phase IV (re-organization) of the offshoring process, but may decrease participation.

The centralization also led to additional structural changes. Formalization increased, as well as specialization and standardization. However, participation reduced in one business unit. As expected, offshoring presents more complexity, often unanticipated by the firm (Bals et al. 2013). Among the complexities are changes in supply and business networks, which represent an increase in variety. The firm must confront such variety, if it is to effectively compete (Espejo 2000). The firm answers to the increases in variety by clearly defining authority levels for better decision-making. A clear span of control provides PSM with a framework for managing functional goals, improving efficiency (Trent 2004). One way to offset the impact of changes in authority and span is by enhancing the PSOs set of competences by investing in skills improvement programs, training, professionalism and increasing PSM's staff reward systems (David et al. 2002; Trent 2004). In addition, clarity of rules on how PSM activities should be carried out and by whom, i.e. clear roles and responsibilities, provides better capabilities development and improves PSM effectiveness in general. In fact, Kim (2007:340) suggests that changes such as increased control and formalization provide the PSO with "adequate level of balance and harmony with other functional areas", which forms the basis for organizational stability and improved firm performance. Thus, we propose:

Proposition 5b: Increasing centralization facilitates further changes in structure (formalization, standardization, specialization) which increase stability of the PSO during phase IV (re-organization) of the offshoring process.

With regards to participation, our offshoring scenario leads to an increase in centralization which is creating structural distance between business units, hence the variations in levels of participation. The divide has two elements to it: One is purely a power or authority issue, which we discussed above and the other is an operational and functional issue. Regarding the latter, the politics and the frustrations of job losses as well as change of roles affect team relationships and may increase team conflict (Johnson and Leenders 2006). However, it can also be argued that structural distance is good for team autonomy. Espejo (2000) showed that autonomy is fundamental for self-regulation because most organizational variety is locally situated. It is therefore possible that centralization paradoxically allows cross-business unit teams to focus on specific and local issues, which enhances autonomy and local control. In fact, Bourgault et al. (2008) found that autonomy improved the quality of decision-making, since teams in dispersed organizations are motivated mostly by project goals, rather than power. In other words, cross-business unit teams do not rely on centralization alone to function effectively (Hartmann et al. 2008). Thus, we propose:

Proposition 5c: Increasing centralization leads to varying levels of participation in the PSO, but can increase autonomy for cross-business unit teams and thereby improve effective decision-making in the PSO during phase IV (re-organization) of the offshoring process. 


\section{Conclusions, limitations and suggestions for future research}

We set out to answer the research question: "How does the purchasing and supply organization (PSO) evolve as a result of captive offshoring of production?" Based on our processual analysis it was shown that the five structural dimensions of (de)centralization, participation, formalization, standardization and specialization show different variations depending on the status of change within the organization. After analysis of the case, propositions were developed and summarized within Figure 3 with regards to the nature of change and the mechanisms PSM adopts when responding to organizational change. Therefore, this study contributes to the understanding of the changes necessary in PSO structure as the firm undergoes changes such as relocation of production. An enhanced understanding can enable firms to choose the most effective configuration of PSM activities at each phase of the change. Based on our in-depth case analysis of the PSO change process we contribute to the PSM literature in three major ways:

First, we highlight that the law of requisite variety influences PSO change trajectories. In 2012, Jay Galbraith predicted that the future of organizational design was going to be shaped by three factors: (1) concatenation, where companies would become more complex through increasingly adding strategic activities onto their structures; (2) the law of requisite variety of Ashby (1956), where organizations would increase their internal variety, when variety in their external environments increases, and (3), technologies of the next industrial revolution, where organizations will change the way they organize themselves using technology. In line with Galbraith (2012) and Ashby's law of requisite variety (1956), the amount of variety faced by the firm predicts the evolution of the PSO as the firm progresses with offshoring of production, but our study underlines the disjointed and non-linear nature of PSO change processes. This is a new finding in addition to the incremental and linked stage models available in literature (e.g. Trent and Monczka 2003; Matthyssens et al. 2003; Jia et al. 2014a). The idiosyncrasy of each state can be seen as a result of the differentiated variety balance the firm is confronted with at any particular period of time (Beer 1985; Espejo 2000). For example, organizations can be skeptical to make any significant PSO changes as they prepare to offshore production and we argue that this tread-carefully approach particularly applies when the variety the PSO faces is high and purchasing maturity is low. These observations how the organization reacts to variety answers requests by Roza et al. (2011) to clarify the co-evolutionary dynamism of offshoring and emergence of new organizational forms in specific business functions. It adds to the literature by suggesting to study variety's influence on the PSO dimensions formalization, specialization and participation during change processes, including purchasing maturity as a moderator for that influence.

Second, we show that the basis of organizing PSM activities during a disruptive process may be a minimalist, or "fluid" configuration. High variety situations that occur simultaneously blur decisionmaking. Contrary to the conventional project management assumption that projects have to be firmly managed according to deadlines and deliverables, the fluid state came out to be the most realistic one during the second phase of transfer. Increasing the level of participation was in a way a means to let the unstable system's members organize themselves. 
Third, the study partly confirms what other studies (e.g. Tate and Ellram 2012) have found, i.e. that formalization, specialization and standardization tend to increase with offshoring. However, we also find that there are differences in levels of participation within the PSO as a result of team autonomy and geographical distance between business units. We suggest that finding the right balance of which PSM tasks should be performed locally and those to be performed globally increases PSM efficiency; it enhances team autonomy without necessarily sacrificing cross-functional integration.

Towards managerial implications, this case study offers important lessons for PSM practitioners, particularly how organizational change affects PSM operations. It suggests that offshoring "destabilizes" PSM competencies in the company, at least when the initial purchasing maturity is low. Therefore, effective PSM managers must find means of retaining this knowledge internally, keeping the best talent in PSM during offshoring. This requires a PSO structure that supports how this knowledge is to be transferred and retained during offshoring. The study also urges PSM managers to stay ahead of change developments within their firms. If PSM cannot influence the firm's change trajectory to keep the benefits of the former structure, it may have great difficulties to make any improvements, resulting in declining PSM performance. Based on the findings for phase III such projects offer momentum for thorough change, which PSM managers may seize proactively. In doing so the "fluid" state findings suggest that managers would do well to manage stakeholder expectations that there might be phases in which the structure is limitedly clear, but momentum for increasing PSM's participation and thus strengthening its strategic role within the firm is created.

The rich in-depth analysis allowed us to study the multi-level change processes at two levels corporate and within the PSO. Moreover, being able to follow manifestations over the phases studied using both retrospective and current data was revealing. Nevertheless, acknowledging that generalization of our study's results is limited due to the single case study design, we strongly suggest a case study replication approach, to further explore and refine the propositions. For future research, this study offers the opportunity to investigate whether from a contingency theory perspective the same patterns hold true for changing sample variables such as size, industry and purchasing maturity. Another interesting aspect for future research would be to study the leader-follower dynamics in such settings, as IPO followership has emerged as a construct in research on establishing International Purchasing Offices in China (Jia et al. 2014b). This is similar to our research setting (which was about relocating PSO activities), in that new coordination mechanisms within the PSO emerge when another unit is established. Finally, the effect of such transitions on the needed resources/capabilities within the PSO would be of interest, in analogy to such changing requirements in the IPO setting (Sartor et al. 2015). The use of real-time data over time is suggested or a combinatory approach with the critical incident technique as in this research.

Summarizing, offshoring projects that captively relocate production to other countries do not only pose challenges to PSM, but offer it opportunities for increasing its profile and becoming a more prominent function. By responding to the newly faced variety with respective PSO adaptations (e.g. in participation), it can come through with stronger market intelligence, innovation and more advanced total cost of ownership (TCO) prospects than ever. 


\section{References}

Andersson U, Pedersen T (2010) Organizational design mechanisms for the R\&D function in a world of offshoring. Scandinavian Journal of Management 26(4):431-438

Arnold U (1999) Organization of global sourcing: ways towards an optimal degree of centralization. European Journal of Purchasing \& Supply Management 5(3):167-174

Ashby WR (1956) An Introduction to Cybernetics. Chapman \& Hall, London

Bals L, Kirchoff JF, Foerstl K (2016) Exploring the reshoring and insourcing decision making process: toward an agenda for future research, Operations Management Research:1-9

Bals L, Daum A, Tate W (2015) From offshoring to rightshoring: Focus on the backshoring phenomenon. AIB Insights 15(4):3-8

Bals L, Jensen PDØ, Larsen MM, Pedersen T (2013) Exploring Layers of Complexity in Offshoring Research and Practice. In: Pedersen T, Bals L, Jensen PDØ, Larsen MM (eds) The Offshoring Challenge: Strategic Design and Innovation for Tomorrow’s Organization. Springer, London, pp 1-18

Barratt M, Choi TY, Li M (2011) Qualitative case studies in operations management: Trends, research outcomes, and future research implications. Journal of Operations Management 29(4): 329-342

Beer S (1985) Diagnosing the System for Organizations. John Wiley \& Sons, Hoboken

Bourgault M, Drouin N, Hamel É (2008) Decision making within distributed project teams: An exploration of formalization and autonomy as determinants of success. Project Management Journal 39(S1):97-110

Burns T, Stalker GM (1961) The management of innovation. Tavistock Publications, London

Bryman B, Bell E (2011) Business Research Methods, 3rd edn. Oxford University Press, Oxford

Caniato F, Caridi M, Crippa L, Moretto A (2012) Environmental sustainability in fashion supply chains: An exploratory case based research. International Journal of Production Economics, 135(2):659-670

Chakravarthy BS (1982) Adaptation: A promising metaphor for strategic management. Academy of Management Review 7(1):35-44

Chung W, Yam A, Chan M (2004) Networked enterprise: A new business model for global sourcing. International Journal of Production Economics 87(3):267-280

Wasserman N (2008) Revisiting the strategy, structure, and performance paradigm: The case of venture capital. Organization Science 19(2):241-259

Colombo M, Delmastro M (2002) The Determinants of Organizational Change and Structural Inertia: Technological and Organizational Factors. Journal of Economics \& Management Strategy 11(4):595-635

Contractor FJ, Kumar V, Kundu SK, Pedersen T (2010) Reconceptualizing the Firm in a World of Outsourcing and Offshoring: The Organizational and Geographical Relocation of High-Value Company Functions. Journal of Management Studies 47(8):1417-1433

Chandler AD (1962) Strategy and structure: Chapters in the history of the American enterprise, Massachusetts Institute of Technology, Cambridge

Creswell JW, Miller DL (2000) Determining validity in qualitative inquiry. Theory into Practice 39(3):124-130

Da Silva Gonçalves Zangiski M, Pinheiro de Lima E, Gouvea da Costa S (2013) Organizational competence building and development: Contributions to operations management. International Journal of Production Economics 144(1):76-89 
David JS, Hwang Y, Pei BK, Reneau, JH (2002) The performance effects of congruence between product competitive strategies and purchasing management design. Management Science 48(7):866-885

Dawson P (1997) In at the deep end: conducting processual research on organizational change. Scandinavian Journal of Management 13 (4):389-405

Dawson P (1994) Organizational change: A processual approach. Paul Chapman, London

Day M, Atkinson DJ (2004) Large-scale transitional procurement change in the aerospace industry. Journal of Purchasing and Supply Management 10(6):257-268

Dubois A, Wynstra F (2005) Organizing the purchasing function as an interface between internal and external networks. Proceedings of the 21st Annual IMP Conference, 1-3 September 2005, Rotterdam, The Netherlands

Ellram L, Tate W, Petersen K (2013) Offshoring and reshoring: an update on the manufacturing location decision. Journal of Supply Chain Management 49(2):14-22

Espejo R (2000) Giving requisite variety to strategic and implementation processes: theory and practice. Paper prepared for JAIST Conference, Ishikawa, Japan

Flanagan JC (1954) The critical incident technique. American Psychological Association 51(4):327-358

Foerstl K, Kirchoff JF, Bals L (2016) Reshoring and Insourcing: Drivers and Future Research Directions, International Journal of Physical Distribution and Logistics Management 46(5):1-24

Fratocchi L, Di Mauro C, Barbieri P, Nassimbeni G, Zanoni A (2014) When manufacturing moves back: concepts and questions. Journal of Purchasing and Supply Management 20(1):1-6

Galbraith J (2012) The Future of Organization Design. Journal of Organization Design 1(1):3-6

Geisler C (2004) Analyzing streams of language: Twelve steps to the systematic coding of text, talk, and other verbal data. Pearson Longman, New York

Gephart RP (2004) Qualitative research and the Academy of Management Journal. Academy of Management Journal 47(4): 454-462

Gioia DA, Corley KG, Hamilton AL (2013) Seeking qualitative rigor in inductive research notes on the gioia methodology. Organizational Research Methods 16(1):15-31

Glock C, Hochrein S (2011) Purchasing Organization and Design: a literature review. BuR Business Research Journal 4(2):149-191

Govindarajan V (1986) Decentralization, strategy, and effectiveness of strategic business units in multibusiness organizations. Academy of Management Review 11(4):844-856

Gray JV, Skowronski K, Esenduran G, Rungtusanatham JM (2013) The reshoring phenomenon: What supply chain academics ought to know and should do. Journal of Supply Chain Management 49(2):27-33

Greenwood R, Hinings CR (1988) Organizational design types, tracks and the dynamics of strategic change. Organization Studies 9(3):293-316

Hartmann E, Trautmann G, Jahns C (2008) Organizational design implications of global sourcing: A multiple case study analysis on the application of control mechanisms. Journal of Purchasing and Supply Management 14(1):28-42

Hinings CR (1997) Reflections on processual research. Scandinavian Journal of Management 13(4): 493-503.

Hult GTM, Ketchen Jr DJ, Nichols Jr EL (2003) Organizational learning as a strategic resource in supply management. Journal of Operations Management 21(5):541-556 
Jahns C, Hartmann E, Bals L (2006) Offshoring: dimensions and diffusion of a new business concept, Journal of Purchasing and Supply Management 12(4):218-231

Jensen PD $\varnothing$ (2009) A learning perspective on the offshoring of advanced services. Journal of international Management 15(2):181-193

Jensen PDØ, Larsen MM, Pedersen T (2013) The organizational design of offshoring: Taking stock and moving forward. Journal of international Management 19(4):315-323

Jia F, Lamming R, Sartor M, Orzes G, Nassimbeni G (2014a) International purchasing offices in China: A dynamic evolution model. International Business Review 23(3):580-593

Jia, F, Lamming, R, Sartor, M, Orzes, G, Nassimbeni, G (2014b) Global purchasing strategy and International Purchasing Offices: Evidence from case studies, International Journal of Production Economics 154: 284-298

Johanson J, Vahlne JE (1977) Internationalization process of firm - model of knowledge development and increasing foreign market commitments. Journal of International Business Studies 8(1):23-32

Johanson J, Wiedersheim-Paul F (1975) The internationalization of the firm-four swedish cases. Journal of Management Studies 12(3):305-323

Johnson PF, Leenders MR (2006) A longitudinal study of supply organizational change. Journal of Purchasing and Supply Management 12(6):332-342

Johnson PF, Leenders MR (2004) Implementing organizational change in supply towards decentralization. Journal of Purchasing and Supply Management 10(4):191-200

Johnson PF, Leenders MR (2003) Gaining and losing pieces of the supply chain. Journal of Supply Chain Management 39(1):27-39

Johnson PF, Leenders MR (2001) The supply organizational structure dilemma. Journal of Supply Chain Management 37(2):4-11

Johnston WJ, Bonoma, TV (1981) The buying center: structure and interaction patterns. The Journal of Marketing 45(3):143-156

Kast F, Rosenzweig J (1973) Contingency Views of Organization and Management. Chicago: Science Research Associates

Ketokivi M, Choi T (2014) Renaissance of case research as a scientific method, Journal of Operations Management 32(5):232-240

Kim S (2007) Organizational structures and the performance of supply chain management. International Journal of Production Economics 106(2):323-345

Kim KK (1990) Task characteristics, decentralization, and the success of hospital information systems. Information \& Management 19(2):83-93

Kinkel S (2014) Future and impact of backshoring-Some conclusions from 15 years of research on German practices. Journal of Purchasing and Supply Management 20(1):63-65.

Kinkel S (2012) Trends in production relocation and backshoring activities: changing patterns in the course of the global economic crisis. International Journal of Operations \& Production Management 32(6):696-720

Kinkel S, Maloca S (2009) Drivers and antecedents of manufacturing offshoring and backshoring-A German perspective. Journal of Purchasing and Supply Management 15(3):154-165

Kotabe M, Mol MJ, Ketkar, S (2008) An evolutionary stage model of outsourcing and competence destruction: A triad comparison of the consumer electronics industry. Management International Review 48(1):65-94 
Kotteaku AG, Laios LG, Moschuris SJ (1995) The influence of product complexity on the purchasing structure. Omega 23 (1):27-39

Lampel J, Bhalla A (2011) Living with offshoring: The impact of offshoring on the evolution of organizational configurations. Journal of World Business 46(3):346-358

Langley A (1999) Strategies for theorizing from process data. Academy of Management Review 24(4):691-710

Larsen MM, Manning S, Pedersen T (2013) Uncovering the hidden costs of offshoring: The interplay of complexity, organizational design, and experience. Strategic Management Journal 34(5):533-552

Lawrence PR, Lorsch JW (1967) Organization and environment. Harvard University Press, Boston

Lewin JE, Johnston WJ (1996) The effects of organizational restructuring on industrial buying behavior: 1990 and beyond. Journal of Business \& Industrial Marketing 11(6):93-111

Lincoln YS, Guba EG (1985) Naturalistic inquiry. Sage, Beverly Hills

Luzzini D, Ronchi S (2011) Organizing the purchasing department for innovation. Operations Management Research 4(1-2):14-27

Manning S, Massini S, Lewin AY (2008) A Dynamic Perspective on Next-Generation Offshoring: The Global Sourcing of Science and Engineering Talent, The Academy of Management Perspectives 22(3): 35-54

Matthyssens P, Quintens L, Faes W (2003) A process model of global purchasing. Journal of Customer Behaviour 2(3):305-327

Meyer MH, Curley, KF (1991) An applied framework for classifying the complexity of knowledge-based systems MIS Quarterly 15(4):455-472

Mol MJ (2003) Purchasing's strategic relevance. Journal of Purchasing and Supply Management 9(1):43-50

Mol MJ, Van Tulder RJ, Beije PR (2005) Antecedents and performance consequences of international outsourcing. International Business Review 14(5):599-617

Mudambi R, Venzin M (2010) The strategic nexus of offshoring and outsourcing decisions. Journal of Management Studies 47(8):1510-1533

Mugurusi G, De Boer L (2013) What follows after the decision to offshore production? Strategic Outsourcing: An International Journal 6(3):213-257

Oshri I (2011) Offshoring strategies: Evolving captive center models. Cambridge, Massachusetts: MIT Press.

Pearson JN, Ellram LM, Carter CR (1996) Status and recognition of the purchasing function in the electronics industry. International Journal of Purchasing and Materials Management 32(1):30-36

Pennings JM (1992) Structural contingency theory-a reappraisal. Research in Organizational Behavior, 14:267309

Pettigrew AM (1997) What is a Processual Analysis? Scandinavian Journal of Management 13(4):337-348

Pettigrew AM (1990) Longitudinal field research on change: theory and practice. Organization Science 1(3):267292

Pettigrew AM, Woodman RW, Cameron KS (2001) Studying organizational change and development: challenges for future research. Academy of Management Journal 44(4):697-713

Quintens L, Pauwels P, Matthyssens P (2006) Global purchasing strategy: Conceptualization and measurement. Industrial Marketing Management 35(7):881-891

Rajagopal S, Bernard KN (1994) Creating strategic change in procurement orientation: a strategy for improving competitiveness. European journal of purchasing \& supply management 1(3):149-160 
Roza M, Van den Bosch FA, Volberda HW (2011) Offshoring strategy: Motives, functions, locations, and governance modes of small, medium-sized and large firms. International Business Review 20(3):314-323

Rozemeijer F (2000) How to manage corporate purchasing synergy in a decentralised company? Towards design rules for managing and organising purchasing synergy in decentralised companies. European Journal of Purchasing \& Supply Management 6(1):5-12

Rozemeijer F, Van Weele A, Weggeman M (2003) Creating Corporate Advantage through Purchasing: Toward a Contingency Model. Journal of Supply Chain Management 39(1):4-13

Sartor M, Orzes G, Nassimbeni G, Jia F, Lamming R (2015) International purchasing offices in China: roles and resource/capability requirements, International Journal of Operations \& Production Management 35(8):11251157

Sartor M, Orzes, G, Nassimbeni G, Jia F, Lamming R (2014) International purchasing offices: Literature review and research directions. Journal of Purchasing and Supply Management 20(1):1-17

Schiele H (2012) Accessing supplier innovation by being their preferred customer. Research-Technology Management, 55(1):44-50

Schiele H (2007) Supply-management maturity, cost savings and purchasing absorptive capacity: Testing the procurement-performance link. Journal of Purchasing and Supply Management 13(4):274-293

Schilling MA, Steensma HK (2001) The use of modular organizational forms: an industry-level analysis. Academy of Management Journal 44(6):1149-1168

Schneider L, Wallenburg CM (2013) 50 Years of research on organizing the purchasing function: Do we need any more? Journal of Purchasing and Supply Management 19(3):144-164

Siggelkow N, Levinthal DA (2003) Temporarily divide to conquer: Centralized, decentralized, and reintegrated organizational approaches to exploration and adaptation. Organization Science 14(6):650-669

Srikanth K, Puranam P (2011) Integrating distributed work: comparing task design, communication, and tacit coordination mechanisms. Strategic Management Journal 32(8):849-875

Stake R (1998) Case Studies. In: Denzin NK, Lincoln YS (eds) Strategies of Qualitative Inquiry. Thousand Oaks, London, Sage, New Delhi pp 134-164

Stanley LL (1993) Linking purchasing department structure and performance-toward a contingency model. Journal of Strategic Marketing 1(3):211-219

Stringfellow A, Teagarden MB, Nie W (2008) Invisible costs in offshoring services work. Journal of Operations Management 26(2):164-179

Stuart I, McCutcheon D, Handfield R, McLachlin R, Samson D (2002) Effective case research in operations management: a process perspective. Journal of Operations Management 20(5):419-433

Tate WL, Ellram LM (2012) Service Supply Management Structure in Offshore Outsourcing. Journal of Supply Chain Management 48(4):8-29

Tate W, Ellram L, Bals L, Hartmann E (2009) Offshore outsourcing of services: An evolutionary perspective. International Journal of Production Economics 120(2):512-524

Tchokogué A, Nollet J, Gobeil K (2011) Supply structure: The pendulum in action. Journal of Purchasing and Supply Management 17(3):148-157

Tiwari V (2010) Transition Process and Performance in IT Outsourcing: Evidence from a Field Study and Laboratory Experiments. Doctoral thesis, Erasmus Research Institute of Management (ERIM) 
Trautmann G, Turkulainen V, Hartmann E, Bals L (2009a) Integration In The Global Sourcing Organization An Information Processing Perspective. Journal of Supply Chain Management 45(2):57-74

Trautmann G, Bals L, Hartmann E (2009b) Global Sourcing in Integrated Network Structures: The Case of Hybrid Purchasing Organizations. Journal of International Management 15(2):194-208

Trent RJ (2004) The use of organizational design features in purchasing and supply management. Journal of Supply Chain Management 40(3):4-18

Trent RJ, Monczka RM (2003) Understanding integrated global sourcing. International Journal of Physical Distribution \& Logistics Management 33(7):607-629

Valle S, García F, Avella L (2015) Offshoring Intermediate Manufacturing: Boost or Hindrance to Firm Innovation? Journal of International Management 21(2):117-134

Van de Ven AH, Huber GP (1990) Longitudinal field research methods for studying processes of organizational change. Organization Science 1(3):213-219

Van Weele AJ (2005) Purchasing and Supply Chain Management: Analysis, Strategy, Planning and Practice, 4th edn. Thompson Learning, London

Vlaar PW, van Fenema PC, Tiwari V (2008) Cocreating understanding and value in distributed work: How members of onsite and offshore vendor teams give, make, demand, and break sense. MIS Quarterly 32(2):227-255

Wasserman, N. (2008) Revisiting the strategy, structure, and performance paradigm: The case of venture capital. Organization Science 19(2):241-259

Westbrook L (1994) Qualitative research methods: A review of major stages, data analysis techniques, and quality controls. Library \& Information Science Research 16(3):241-254

Whitney D, Luo J, Heller D (2014) The benefits and constraints of temporary sourcing diversification in supply chain disruption and recovery. Journal of Purchasing and Supply Management 20(4):238-250

Yin RK (2009) Case study research: Design and methods. 4th edn. Sage, London

Zaheer S (2002) The liability of foreignness, redux: a commentary. Journal of International Management 8:351358 


\section{FIGURES AND TABLES}

Fig. 1: The PSO transition during the production offshoring process

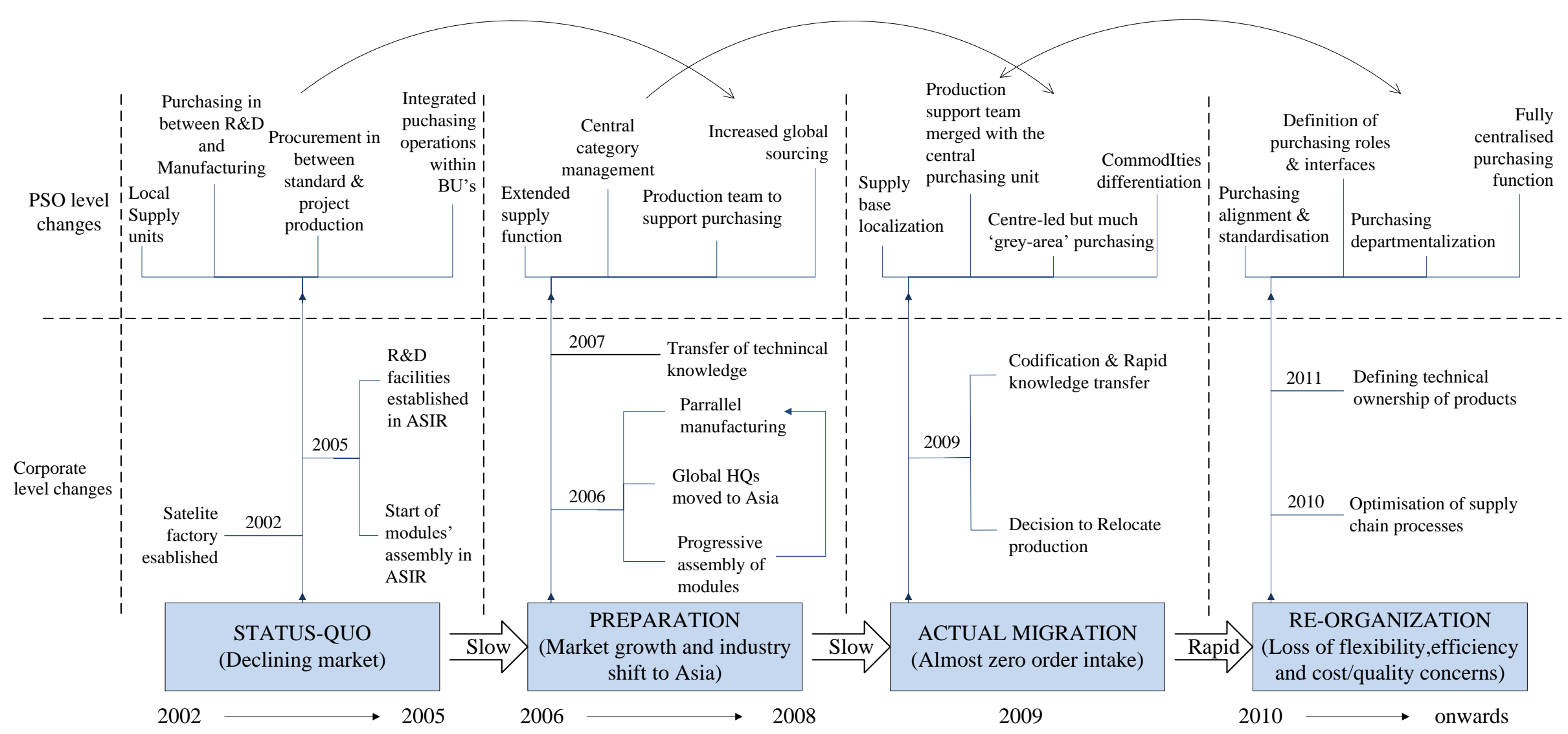


Fig. 2: Events in the PSO evolution from between 2005 to 2010

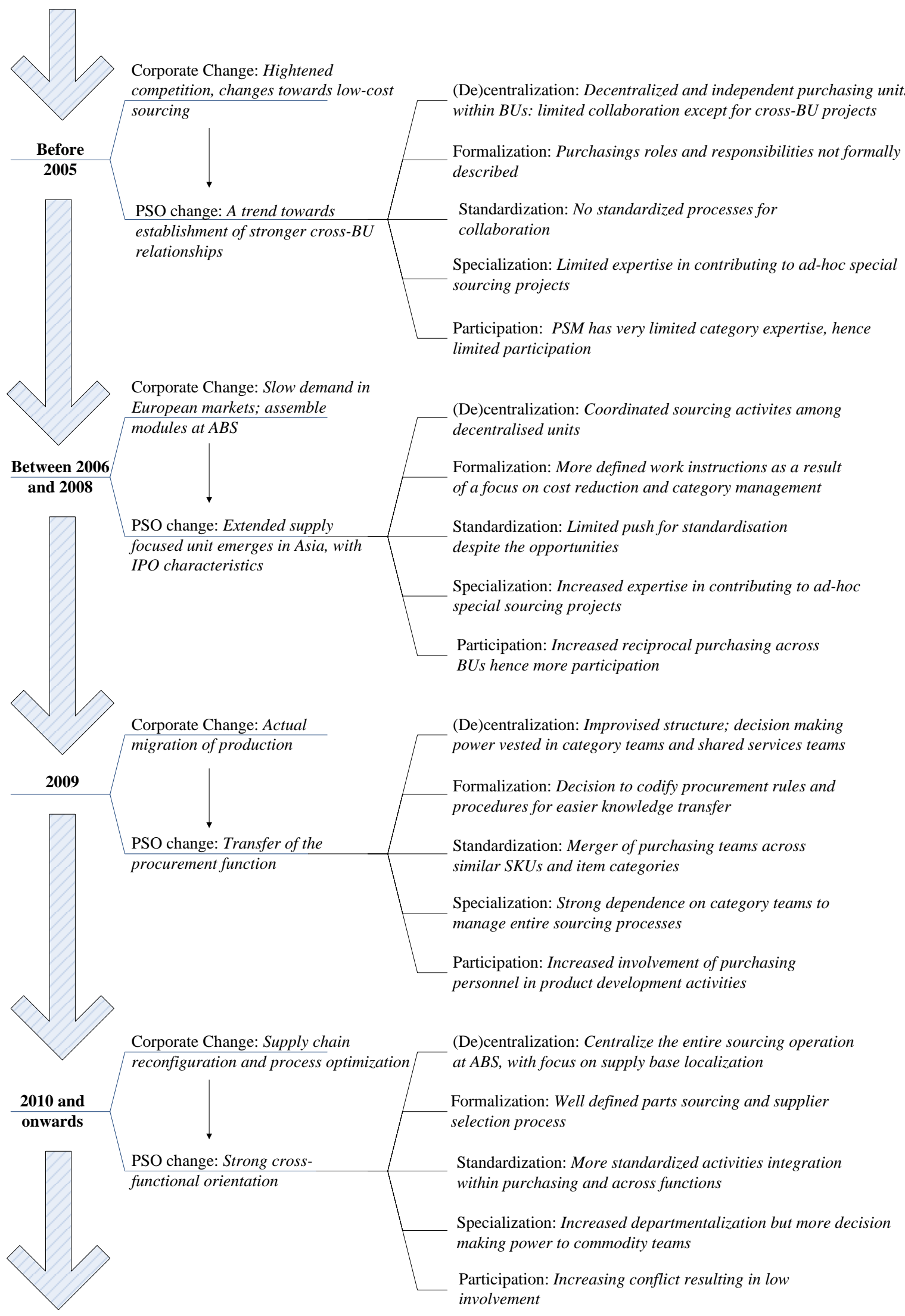


Fig. 3: Resulting framework including the propositions

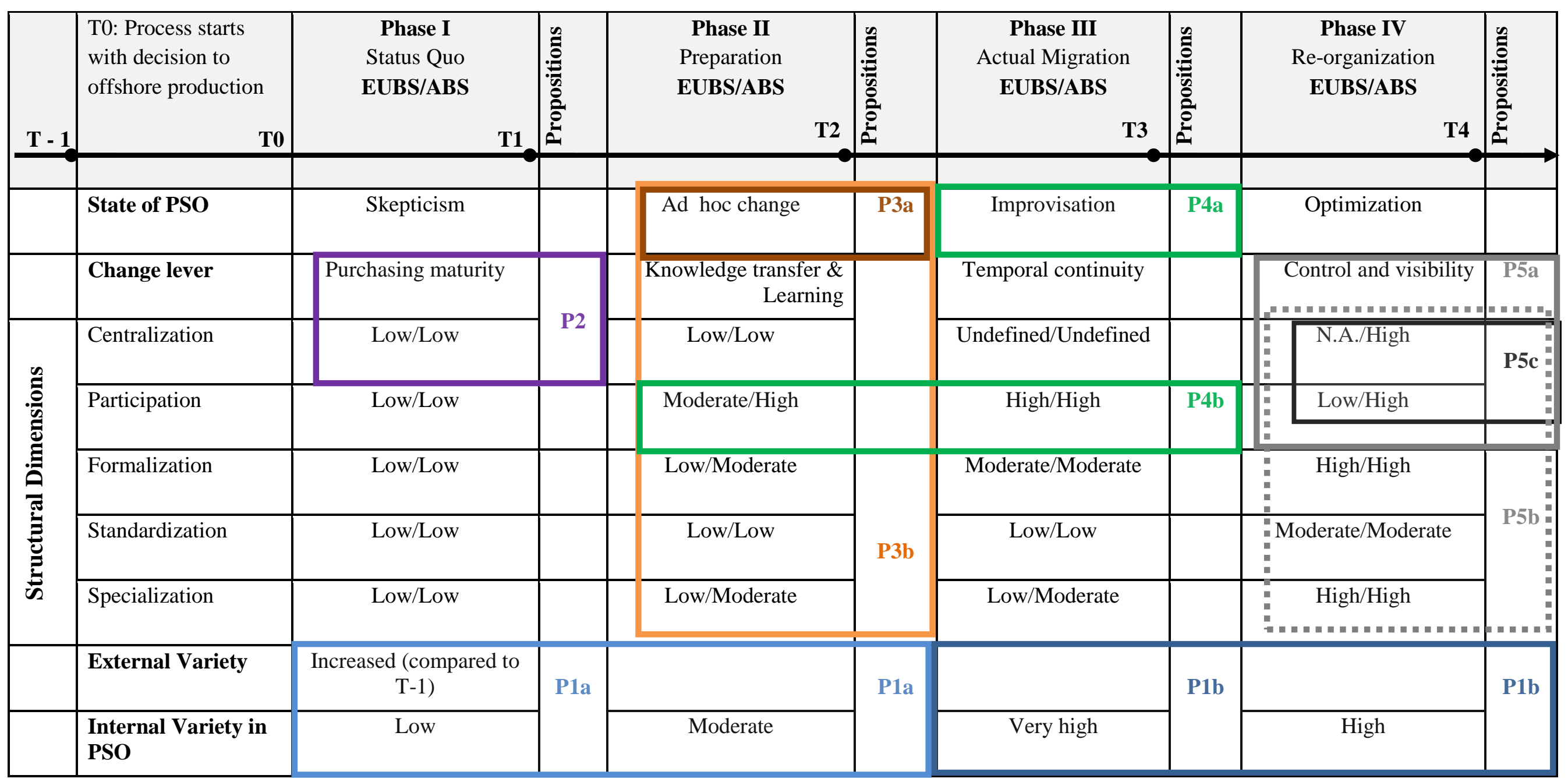


Table 1: Table of definitions, adapted from: Glock and Hochrein (2011:154-158); Johnston and Bonoma, (1981:148); Stanley 1993; Kotteaku et al. 1995; Pearson et al. 1996.

\begin{tabular}{|lll|}
\hline Construct & Definition & Exemplary quote from literature \\
\hline Centralization & $\begin{array}{l}\text { Centralization in our context means that the PSM activities are consolidated } \\
\text { under one organizational unit's authority, responsibility and power versus } \\
\text { decentralized meaning to have multiple units having their own authority, } \\
\text { responsibility and power. }\end{array}$ & $\begin{array}{l}\text { "the degree to which authority, responsibility, and power are concentrated } \\
\text { within an organization or buying unit" (Johnston and Bonoma 1981:148). }\end{array}$ \\
\hline Participation & $\begin{array}{l}\text { The extent of involvement of other organizational members in purchase } \\
\text { decisions. }\end{array}$ & $\begin{array}{l}\text { "the extent to which various organizational members are involved in } \\
\text { decision making" (Johnston and Bonoma 1981:148). }\end{array}$ \\
\hline Formalization & $\begin{array}{l}\text { Degree to which an organization relies on rules and procedures to direct } \\
\text { behavior of its members. }\end{array}$ & $\begin{array}{l}\text { "the extent to which purchasing tasks/roles are defined by various formal } \\
\text { documents describing rules, procedures and policies" (Kotteaku et al. } \\
1995: 30)\end{array}$ \\
\hline Standardization & $\begin{array}{l}\text { Degree to which organizational activities or organizational routines are } \\
\text { precisely defined. }\end{array}$ & $\begin{array}{l}\text { "the degree to which organizational activities or organizational routines } \\
\text { are precisely defined" (Glock and Hochrein 2011:158). }\end{array}$ \\
\hline Specialization & The division of labor in an organization. & $\begin{array}{l}\text { "the degree to which purchasing activities are conducted by specialized } \\
\text { departments, committees and skilled personnel" (Glock and Hochrein } \\
2011: 158) .\end{array}$ \\
\hline
\end{tabular}

Table 2: Similarities and key phases in the offshoring process

\begin{tabular}{|l|c|c|c|c|c|}
\hline Model/perspective & Phase I & Phase II & Phase III & Phase IV & Main Concepts/Theories \\
\hline $\begin{array}{l}\text { Johanson and } \\
\text { Wiedersheim-Paul (1975) }\end{array}$ & No activity & Export via agents & $\begin{array}{c}\text { Establish sales } \\
\text { unit }\end{array}$ & Production \\
\hline Kotabe et al. (2008) & $\begin{array}{c}\text { Captive } \\
\text { offshoring }\end{array}$ & $\begin{array}{c}\text { Offshore } \\
\text { outsourcing - Low }\end{array}$ & $\begin{array}{c}\text { Offshore } \\
\text { High }\end{array}$ & $\begin{array}{c}\text { Reduce } \\
\text { outsourcing }\end{array}$ & $\begin{array}{c}\text { Resource-based View (RBV), } \\
\text { Dynamic Capabilities }\end{array}$ \\
\hline Tiwari (2010) & - & Transfer & Adapt & $\begin{array}{c}\text { Transaction Cost Econominize } \\
\text { (TCE), Resource Dependency, } \\
\text { Organizational Learning }\end{array}$ \\
\hline Mudambi and Venzin (2010) & - & Disintegration & Mobility & Reintegration & $\begin{array}{c}\text { Transaction Cost Economics (TCE) } \\
\text { Ramp-up }\end{array}$ \\
\hline Srikanth and Puranam (2011) & Due diligence & Transition & Steady state & $\begin{array}{c}\text { Modularization, Tacit Coordination } \\
\text { Mechanisms (TCMs) }\end{array}$ \\
\hline Jensen et al. (2013) & - & Disintegration & Relocation & Reintegration & Organizational Reconfiguration \\
\hline
\end{tabular}


Table 3: Details of informants

\begin{tabular}{|c|c|c|c|c|}
\hline Participant & EUBS & ABS & $\begin{array}{l}\# \\
\text { Interviews }\end{array}$ & $\begin{array}{l}\text { Participation in } \\
\text { offshoring process }\end{array}$ \\
\hline Head of Purchasing and Supply Unit (HPSU) & $\sqrt{ }$ & $\sqrt{ }$ & 1 & Change agent \\
\hline Head of Supply Chain Management (SCM) & & $\sqrt{ }$ & 1 & Post-offshoring \\
\hline Tactical Purchasing Manager (TPM) & & $\sqrt{ }$ & 1 & Pre- \& post-offshoring \\
\hline Sourcing Manager (SM) & & $\sqrt{ }$ & 1 & Pre- \& post-offshoring \\
\hline Supplier Quality Manager (SQM) & & $\sqrt{ }$ & 1 & Pre- \& post-offshoring \\
\hline Technical Centre Manager (TCM) & & $\sqrt{ }$ & 1 & Change agent \\
\hline Project Managers (\#1, 2, 3, $4 \&$ 5) & $\sqrt{ }$ & & 5 & Varied roles \\
\hline Global Commodity Manager (GCM) & $\sqrt{ }$ & & 1 & Pre- \& post-offshoring \\
\hline
\end{tabular}

Table 4: Variations in PSO structure during offshoring, framework developed based on Johanson and Wiedersheim-Paul (1975), Kotabe et al. (2008), Tiwari (2010), Mudambi and Venzin (2010), Srikanth and Puranam (2011) and Jensen et al. (2013).

\begin{tabular}{|c|c|c|c|c|}
\hline $\begin{array}{l}\mathrm{T}_{0} \text { Process starts with } \\
\text { Offshoring of production } \rightarrow\end{array}$ & $\begin{array}{c}\mathrm{T}_{1} \text { Phase I } \\
\text { Status Quo } \\
\rightarrow \\
\text { EUBS/ABS }\end{array}$ & $\begin{array}{c}\mathrm{T}_{2} \text { Phase II } \\
\text { Preparation } \\
\rightarrow \\
\rightarrow \\
\text { EUBS/ABS }\end{array}$ & $\begin{array}{c}\mathrm{T}_{3} \text { Phase III } \\
\text { Actual Migration } \\
\rightarrow \\
\text { EUBS/ABS }\end{array}$ & $\begin{array}{c}\mathrm{T}_{4} \text { Phase IV } \\
\text { Re-organization } \\
\rightarrow \\
\text { EUBS/ABS }\end{array}$ \\
\hline Centralization & Low/Low & Low/Low & Undefined/Undefined & N.A./High \\
\hline Participation & Low/Low & Moderate/High & High/High & Low/High \\
\hline Formalization & Low/Low & Low/Moderate & Moderate/Moderate & High/High \\
\hline Standardization & Low/Low & Low/Low & Low/Low & Moderate/Moderate \\
\hline Specialization & Low/Low & Low/Moderate & Low/Moderate & High/High \\
\hline External Variety & $\begin{array}{c}\text { Increased } \\
\left.\text { (compared to } \mathrm{T}_{-1}\right)\end{array}$ & & & \\
\hline Internal Variety in PSO & Low & Moderate & Extremely high & High \\
\hline
\end{tabular}




\section{Appendix A \\ More details on data collection}

Initially the overall head of the Purchasing and Supply Unit (HPSU) who also doubled as the study's gatekeeper to the firm, arranged the first 3 interviews. The 3 informants were asked to suggest more informants and because historical provenance was a critical aspect of the data collection exercise, we targeted change agents and informants that had actively been involved in the implementation of the offshoring strategy between 2005 and 2011. In addition, our sampling targeted informants from the two business units, EUBS and ABS, that: Either (1) had been part of the old PSM function set-up, or (2) were currently responsible for the firm's purchasing and supply operations, or (3), belonged to both categories (1) and (2). These varied sources of data enhance the credibility and descriptive validity of the research findings (Creswell and Miller, 2000). A total of 15 senior and middle managers were contacted. In total 12 interviews were conducted, with each semi-structured interview lasting approximately 1 hour. Some informants were involved in post-data collection activities which included follow-up emails for clarification of the data. Almost all interviews were conducted during the site visits at the NorTex's facilities, one in Asia that doubles as the global headquarters and the other in Europe where production was previously located.

The interview protocol was developed partly in conjunction with a senior researcher and a peer to one of the authors. Semi-structured interview questions span across three broad themes: (1) The offshoring process and timelines; (2) the actual migration process, and (3) the coordination/integration of the PSM function. The informants were notified about the agenda with these topics well in advance. After the first set of interviews was completed, more items were added onto the semi-structured interview protocol under the same themes. This same protocol was then used for all interview sessions carried out at both the old and new facilities, ABS and EUBS respectively.

We gathered secondary data from previous research reports, company presentations, company videos and photos, and several current and past press releases that were built into a database of archival data. More specifically 18 press releases, 2 supplier audit sheets, 1 written memo, 1 published interview of a former CEO, 3 internal videos and third party videos, 4 supplier conference presentations, 5 project documentation and company training documents, 4 company financial reports in both hard and soft copy were analyzed. Also, because the company is part of a publicly listed global conglomerate, we also subscribed to email alerts about the company's performance and investor reports, in addition to the company's weekly updates on social media platforms like LinkedIn and Facebook and industry reports, magazines and publications which were very insightful for the analysis. All this data, together with the interview data, was fed into NVivo, with which the analysis for this paper was performed. 


\section{Appendix B \\ More details on data analysis}

Once initial coding was done, we re-coded our data around the timeline. This technique suggested by both Pettigrew (1997) and Langley (1999), shows how the temporal context influences organizational events or actions. Langley (1999:703) thus states: "the decomposition of data into successive adjacent periods enables the explicit examination of how actions of one period lead to changes in the context that will affect action in subsequent periods".

Subsequently the data were further re-coded for more random themes in relation to the research question. We also coded for the location of voice of informant, i.e. which business unit did the informant work for (EUBS or ABS). This is extremely important in offshoring research because cultural differences, geographical distance differences and knowledge asymmetry have been suggested to affect organizational structural outcomes (Lampel and Bhalla 2011). At first, we carried out open coding as proposed by Gioia et al. (2013), which resulted in over 120 varied codes (such as "level of frustration among team members", and "duplication of tasks") as we searched for any emergent themes from those codes and subsequent codes. For example, these mentioned codes resulted in the themes "functioning of team" and "degree of cooperation and involvement". The second step considered the systematic coding mechanism consistent with Geisler's (2004) methodology, where we looked out for predefined codes on the pre and post offshoring changes among the 5 structural dimensions. This was done in both the open codes earlier captured and the re-coding of the original data in NVivo. Once all data had been coded, the refinement and search for familiar patterns and contradictions began. A resultant data structure was developed from the first order concepts which then was translated into the second themes, from which the aggregate concepts such as "skepticism" and "ad hoc change", as the basis for our discussion emerged. The PSO frame of analysis developed earlier from literature was also used and results tabulated. We attempted as much as possible to stay close to the data (Gioia et al. 2013).

In order to control for investigator bias and enhance structural corroboration, a technique similar to the negative case analysis was used (Westbrook 1994). After all the data had been coded and initial meanings extracted, a post-analysis interview with a former employee that had been actively involved in the offshoring process as a change champion was conducted. The interview sought to critically substantiate the outcomes of the study and to clarify if the outcomes were "a true picture of the phenomenon being studied" (Westbrook 1994:252). 


\section{Appendix C \\ More details on product $\mathbf{Y}$}

Product $\mathrm{Y}$ is a relatively high-end, highly complex and low volume item designed and manufactured as a system, yet $\mathrm{X}$ is largely a standard offering. Production of $\mathrm{Y}$ is based on the engineer-to-order (ETO) model, but the firm receives orders for standardized catalogue models as well. Currently production is based on six variants for large industrial customers in the automotive and aerospace industries. However, the growing electronics industry in Asia has a lot of potential. Both products $\mathrm{X}$ and $\mathrm{Y}$ are high-end, high precision equipment. Aside these two dominant variants, the company also manufactures peripheral equipment, modular manufacturing cells and service applications for both internal and external clients.

The traditional setup of this global engineering company is organized around product groups and while $\mathrm{X}$ and $\mathrm{Y}$ look similar, they are totally different by functionality and configuration. As such, over $80 \%$ of their entire system components differ. For these two product variants, the company had 3 factories until 2009, then one of the two factories in EUBS was relocated to Asia. So the only remnant factory in the EUBS region just manufactures product $\mathrm{X}$ and has limited interactions with the ABS factory now based in Asia where product $Y$, the focus of this study, is manufactured.

Until 2006, the global headquarters for the product Y line was based in North America. After relocation from EUBS to ABS, the Asian facility is currently the HQs and the only facility which manufactures the product Y line, with EUBS a small product development subsidiary of ABS. Prior to the firm's decision to move production and procurement to ABS, EUBS was responsible for research, design and development, procurement, production and sales for the product group Y. The increasing cost of labor, declining market growth and the increasing difficulty of "finding the right people at EUBS" (interview: HPSU) motivated the firm to move production to ABS. Only the R\&D function was retained at EUBS particularly because of the history of product Y, i.e. the world's first of its kind. This is the origin of the problem that we are investigating: How the firm goes about organizing its PSO in a recently disintegrated production environment. 